\title{
The seasonal cycle and interannual variability of surface energy balance and melt in the ablation zone of the west Greenland ice sheet
}

\author{
M. R. van den Broeke, C. J. P. P. Smeets, and R. S. W. van de Wal \\ Institute for Marine and Atmospheric research (IMAU), Utrecht University, P.O. Box 80005, 3508TA Utrecht, \\ The Netherlands \\ Received: 18 February 2011 - Published in The Cryosphere Discuss.: 7 March 2011 \\ Revised: 6 May 2011 - Accepted: 12 May 2011 - Published: 16 May 2011
}

\begin{abstract}
We present the seasonal cycle and interannual variability of the surface energy balance (SEB) in the ablation zone of the west Greenland ice sheet, using seven years (September 2003-August 2010) of hourly observations from three automatic weather stations (AWS). The AWS are situated along the $67^{\circ} \mathrm{N}$ latitude circle at elevations of $490 \mathrm{~m}$ a.s.l. (S5), $1020 \mathrm{~m}$ a.s.l. (S6) and $1520 \mathrm{~m}$ a.s.l. (S9) at distances of 6,38 and $88 \mathrm{~km}$ from the ice sheet margin. The hourly AWS data are fed into a model that calculates all SEB components and melt rate; the model allows for shortwave radiation penetration in ice and time-varying surface momentum roughness. Snow depth is prescribed from albedo and sonic height ranger observations. Modelled and observed surface temperatures for non-melting conditions agree very well, with RMSE's of $0.97-1.26 \mathrm{~K}$. Modelled and observed ice melt rates at the two lowest sites also show very good agreement, both for total cumulative and 10-day cumulated amounts. Melt frequencies and melt rates at the AWS sites are discussed. Although absorbed shortwave radiation is the most important energy source for melt at all three sites, interannual melt variability at the lowest site is driven mainly by variability in the turbulent flux of sensible heat. This is explained by the quasi-constant summer albedo in the lower ablation zone, limiting the influence of the melt-albedo feedback, and the proximity of the snow free tundra, which heats up considerably in summer.
\end{abstract}

\section{Correspondence to:}

M. R. van den Broeke

(m.r.vandenbroeke@uu.nl)

\section{Introduction}

Surface melt and subsequent runoff of meltwater are of primary importance for the mass balance of the Greenland ice sheet (GrIS). Strong interactions exist between surface meltwater production and the sliding behaviour of the ice sheet in west Greenland (Zwally et al., 2005; Van de Wal et al., 2008; Joughin et al., 2008; Shepherd et al., 2009), a process that is linked to the formation and decay of subglacial meltwater channels (Schoof, 2010). The increase in runoff since 1990, following atmospheric warming (Box and Cohen, 2006; Hanna et al., 2008), explains more than half of the recent mass loss of the GrIS (Van den Broeke, 2009a). In the warm summers of 2007 and 2010 (Tedesco et al., 2008, 2011), melting on the GrIS exceeded $600 \mathrm{Gt} \mathrm{yr}^{-1}$, an increase of $>60 \%$ compared to the 1961-1990 average. Especially in areas where the ice sheet borders on tundra, which heats up considerably in summer, summer melt rates can attain 4-5 $\mathrm{m}$ of ice (Van de Wal et al., 2005). If in a future warmer climate the ice sheet further retreats onto the land, surface meltwater runoff will continue to dominate GrIS mass loss, making it a crucial parameter to model correctly.

In the absence of detailed observations, estimating melt and runoff from the GrIS requires the use of a regional atmospheric model that solves the full surface energy balance (SEB) at high spatial resolution (Fettweis, 2007; Ettema et al., 2009; Fettweis et al., 2010). In turn, these models require validation from in situ observations at the ice sheet surface (Ettema et al., 2010a, b). Owing to the difficult terrain in the GrIS ablation zone with crevasses, slush formation and the presence of meltwater lakes (Box and Ski, 2007), only a few SEB time series are available to date (Ambach, 1977; Greuell and Konzelmann, 1994; Oerlemans and Vugts, 1993; Henneken et al., 1994; Van de Wal and Russell, 1994; Bøggild et al., 1994; Konzelmann and Braithwaite, 1995; Heinemann,

Published by Copernicus Publications on behalf of the European Geosciences Union. 
1999). Most experiments lasted only for (part of) a single ablation season, neither capturing the wintertime climate nor the interannual variability.

Automatic weather stations (AWS) may fill these observational gaps in time and space. Since September 2003, the Institute for Marine and Atmospheric Research of Utrecht University (UU/IMAU) has operated three AWS in the ablation zone in west Greenland, as a contribution to the Greenland Climate Network (GC-Net, Steffen and Box, 2001). The AWS are equipped with radiation sensors and two measurement levels for temperature, humidity and wind speed, which makes them especially suitable for SEB studies. Previously, the first four years of AWS data (2003-2007) were used to assess the radiation and turbulent driven heat exchange (Van den Broeke, 2008a, 2009b) and the surface mass balance (Van den Broeke et al., 2008b). This study presents an update, using the longer time series to present the average seasonal cycle of the full energy balance with special reference to interannual variability, including a thorough evaluation of the model under melting and non-melting conditions. The next section describes the AWS data and the SEB model, Sect. 3 presents the model evaluation and the SEB results, followed by a summary and conclusions in Sect. 4 .

\section{Methods}

\subsection{AWS data}

The three AWS are situated along the K-transect, a stake array in southwest Greenland that extends from the ice margin to $1850 \mathrm{~m}$ a.s.l. This part of the GrIS is characterized by a dry and sunny climate, resulting in little wintertime accumulation (Van den Broeke et al., 2008b) and high summertime ablation rates of up to $5 \mathrm{~m}$ near the ice margin (Van de Wal et al., 2005). The AWS masts are not fixed to the ice and sink with the ablating surface, while approximately retaining their upright position. Each site is equipped with an independent sonic height ranger, fixed to the ice, to monitor snow accumulation and snow/ice ablation, as well as one or several aluminium stakes to measure annual net ablation/accumulation at the end of the ablation season. Figure 1 shows the location and surroundings of the three AWS sites S5 (490 m a.s.l.), S6 (1020 ma.s.l.) and S9 (1520 ma.s.l.) superimposed on a MODIS image from 23 August 2006. This time of year marks the end of the ablation season, when the bare ice extent is at a maximum; clearly visible are the bare ice zone (greyish, between 500-1500 m a.s.l.), the superimposed ice zone (milky blue, 1500-1750 m a.s.l.) and the snow-covered percolation zone (bright white, $1750 \mathrm{~m}$ a.s.l. and higher). Melting of dust-rich glacier ice causes the dark band in the middle ablation zone (Wientjes and Oerlemans, 2010). Strong interactions between surface meltwater production and ice dynamics have been observed along the K-transect (Van de Wal et al., 2008; Shepherd et al., 2009).
Half-hourly averages of air pressure, shortwave/longwave incoming/outgoing radiation components and two-level wind speed/direction, temperature and relative humidity are stored at the AWS and retrieved each year in August or September. Table 1 lists the sensor specifications and Table 2 the period of operation, location information and basic climate and surface energy balance statistics. Radiation, temperature and humidity observations are corrected along the lines described in Van den Broeke et al. (2004, 2008a). Owing to a datalogger failure, S6 misses data from September 2007 to August 2008, and for several weeks in June, July and August 2010. This prevented the calculation of averages for those months at S6.

The SEB model requires time series of snow depth, instrument height and surface momentum roughness $z_{0}$. The first step is to determine whether ice or snow is present at the surface; for this, a combination of albedo $\left(\mathrm{SW}_{\mathrm{in}} /\left|\mathrm{SW}_{\text {out }}\right|\right)$ and surface height measurements is used, where we use the previous end of summer ice surface as a base horizon to determine the snow depth at the start of the melt season (May). As an example, Fig. 2 shows the evolution of albedo (blue line), surface level from the sonic height ranger (orange line), the deduced ice horizon (red line) and derived snow depth (green line) at S6 for the summer of 2004. After the thin layer $(25 \mathrm{~cm})$ of winter snow has melted, background albedo gradually decreases in the course of the melt season. This slow evolution is probably caused by snow metamorphism under the influence of melt and partly by the fact that the radiation sensor, mounted at approximately $6 \mathrm{~m}$ above the surface, "sees" a much larger surface area (approximately $100 \mathrm{~m}^{2}$ ) than the sonic height ranger, which is located closer to the surface and has a smaller viewing angle. Even when the snow may have disappeared under the sonic height ranger, the radiation sensor still detects patches of snow, usually in gullies, keeping the albedo well above 0.6 . Only after these patches have completely melted away towards the end of the ablation season, does the albedo reach the value of glacier ice (approximately 0.55). Superimposed on this gradual background decrease in albedo are rapid fluctuations. These are caused by summer snowfall events, and in spite of their small magnitude (typically $<5 \mathrm{~cm}$ ) are important because they temporarily reduce or even halt surface ice melt. The combination of albedo and sonic height ranger data is used to derive snow depth at S5 and S6 for the full observational period. Albedo measurements at S9 suggest that glacier ice did not surface there (supported by ground observations), and a semi-infinite snowpack is prescribed for that site. Instrument levels (heights above the surface) are reconstructed based on the derived snow depths and reference measurements during annual station visits. In combination with the two-level wind speed, temperature and humidity data this information is used to calculate 20-day running means of surface momentum roughness $z_{0}$ (Smeets and Van den Broeke, 2008a; Van den Broeke et al., 2009b). 

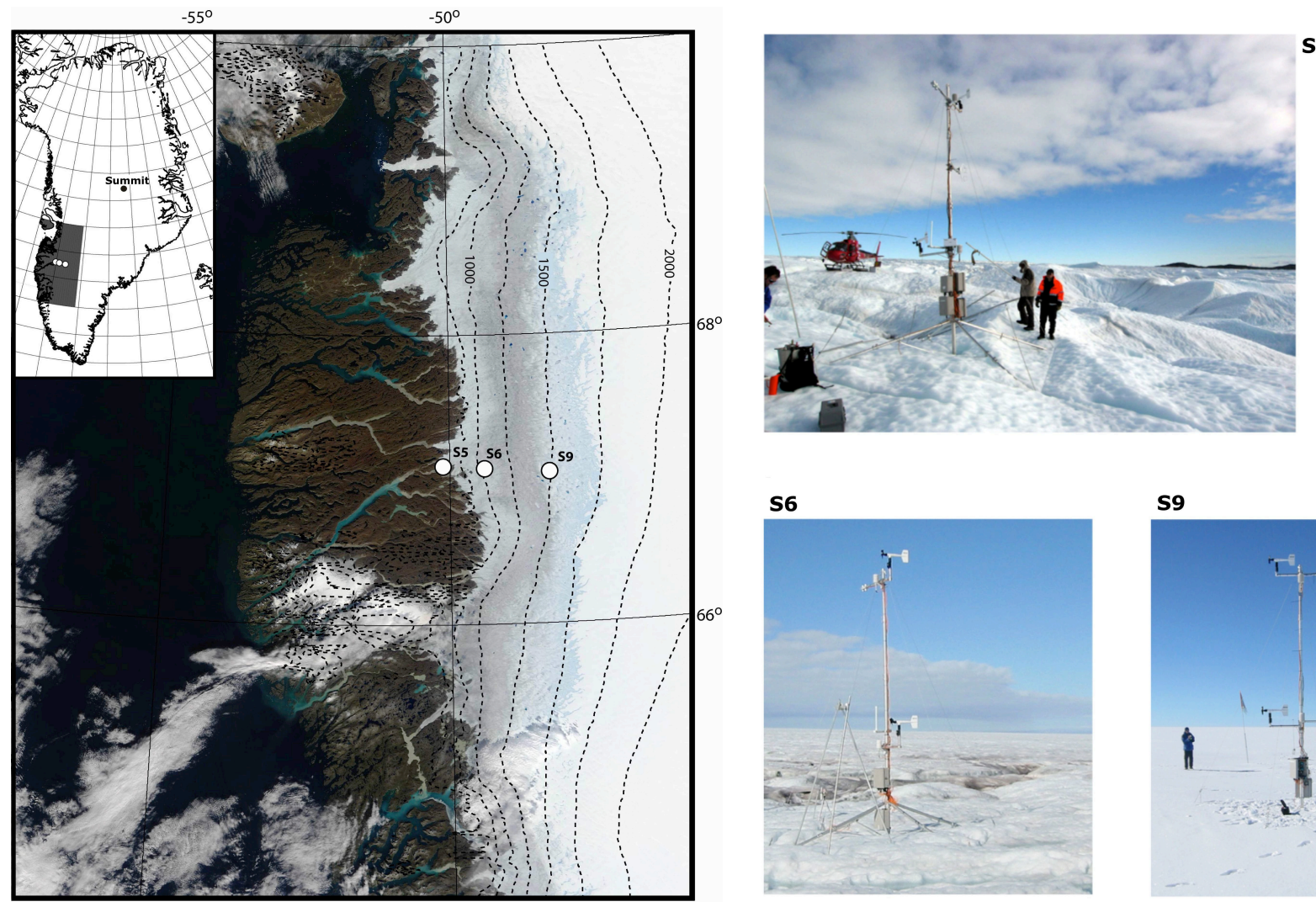

S6

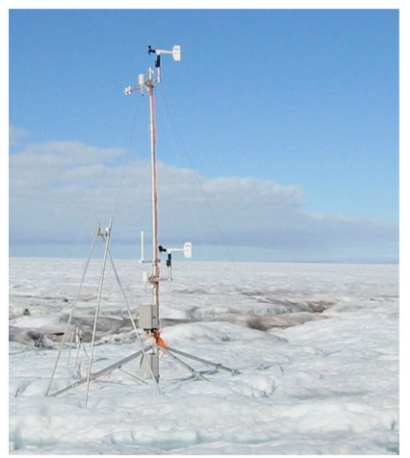

S9

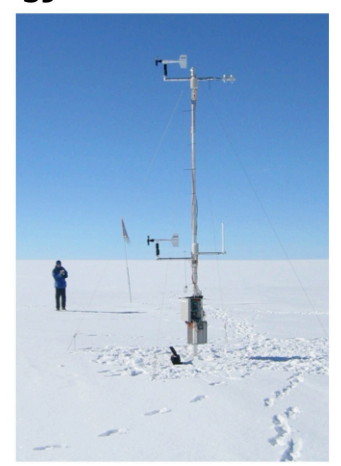

Fig. 1. Left: MODIS scene of west Greenland (23 August 2006) with AWS locations (white dots) and ice sheet elevation contours (dashed lines, height interval $250 \mathrm{~m}$, from Bamber et al., 2001). Inset shows location of Summit. Right: images of AWS locations at S5 (27 August 2006), S6 and S9 (both 26 August 2006).

Table 1. AWS sensor specifications. EADT = Estimated Accuracy for Daily Totals.

\begin{tabular}{llll}
\hline Sensor & Type & Range & Accuracy \\
\hline Air pressure & Vaisala PTB101B & 600 to $1060 \mathrm{hPa}$ & $4 \mathrm{hPa}$ \\
Air temperature & Vaisala HMP35AC & -80 to $+56^{\circ} \mathrm{C}$ & $0.3^{\circ} \mathrm{C}$ \\
Relative humidity & Vaisala HMP35AC & 0 to $100 \%$ & $2 \%(\mathrm{RH}<90 \%)$ \\
& & & $3 \%(\mathrm{RH}>90 \%)$ \\
Wind speed & Young 05103 & 0 to $60 \mathrm{~m} \mathrm{~s}^{-1}$ & $0.3 \mathrm{~m} \mathrm{~s}^{-1}$ \\
Wind direction & Young 05103 & 0 to $360^{\circ}$ & $3^{\circ}$ \\
Pyranometer & Kipp en Zonen CM3 & 305 to $2800 \mathrm{~nm}$ & EADT $\pm 10 \%$ \\
Pyrradiometer & Kipp en Zonen CG3 & 5000 to $50000 \mathrm{~nm}$ & EADT $\pm 10 \%$ \\
Snow height & Campbell SR50 & 0.5 to $10 \mathrm{~m}$ & $0.01 \mathrm{~m}$ or $0.4 \%$ \\
\hline
\end{tabular}

\subsection{SEB model}

The SEB of a "skin" layer is given by:

$$
\begin{aligned}
M & =\mathrm{SW}_{\text {in }}+\mathrm{SW}_{\text {out }}+\mathrm{LW}_{\text {in }}+\mathrm{LW}_{\text {out }}+\mathrm{SHF}+\mathrm{LHF}+G_{\mathrm{S}} \\
& =\mathrm{SW}_{\text {net }}+\mathrm{LW}_{\text {net }}+\mathrm{SHF}+\mathrm{LHF}+G_{\mathrm{S}} \\
& =R_{\text {net }}+\mathrm{SHF}+\mathrm{LHF}+G_{\mathrm{s}}
\end{aligned}
$$

where $M$ is melt energy, $\mathrm{SW}_{\mathrm{in}}, \mathrm{SW}_{\text {out }}$ and $\mathrm{SW}_{\text {net }}$ are incoming, reflected and net shortwave radiation fluxes, $\mathrm{LW}_{\mathrm{in}}$, $\mathrm{LW}_{\text {out }}$ and $\mathrm{LW}_{\text {net }}$ are incoming, emitted and net longwave radiation fluxes, $R_{\text {net }}$ is the net radiation flux, SHF and LHF are the turbulent fluxes of sensible and latent heat and $G_{\mathrm{s}}$ is the subsurface (conductive) heat flux, evaluated at the surface. All terms are in $\mathrm{W} \mathrm{m}^{-2}$ and defined positive when directed towards the surface. Here we briefly repeat the main 
Table 2. AWS topographic, climate and surface energy balance characteristics. Similarity theory is used to obtain temperature, humidity and wind speed at standard heights from AWS observations. All SEB values are derived from the SEB model apart from $\mathrm{SW}_{\text {in }}, \mathrm{SW}_{\text {out }}$ and $\mathrm{LW}_{\mathrm{in}}$, which are from (corrected) observations.

\begin{tabular}{|c|c|c|c|}
\hline & S5 & S6 & S9 \\
\hline \multicolumn{4}{|l|}{ Location (August 2006) } \\
\hline Latitude $(\mathrm{N})$ & $67^{\circ} 06^{\prime}$ & $67^{\circ} 05^{\prime}$ & $67^{\circ} 03^{\prime}$ \\
\hline Longitude (W) & $50^{\circ} 07^{\prime}$ & $49^{\circ} 23^{\prime}$ & $48^{\circ} 14^{\prime}$ \\
\hline Elevation (m a.s.1.) & 490 & 1020 & 1520 \\
\hline Distance from ice edge $(\mathrm{km})$ & 6 & 38 & 88 \\
\hline \multicolumn{4}{|c|}{ Period of operation used for this paper } \\
\hline Start of observation & 1 September 2003 & 1 September 2003 & 1 September 2003 \\
\hline End of observation & 31 July 2010 & 31 July $2010^{*}$ & 31 July 2010 \\
\hline \multicolumn{4}{|l|}{ Annual average climate variables } \\
\hline Surface mass balance (m w.e.) & -3.6 & -1.5 & $\sim 0$ \\
\hline $2 \mathrm{~m}$ temperature $(\mathrm{K})$ & 267.2 & 263.3 & 260.4 \\
\hline $2 \mathrm{~m}$ relative humidity $(\%)$ & 75 & 87 & 89 \\
\hline $2 \mathrm{~m}$ specific humidity $\left(\mathrm{g} \mathrm{kg}^{-1}\right)$ & 2.3 & 2.1 & 1.9 \\
\hline $10 \mathrm{~m}$ wind speed $\left(\mathrm{m} \mathrm{s}^{-1}\right)$ & 5.3 & 6.9 & 7.9 \\
\hline \multicolumn{4}{|c|}{ Annual average surface energy balance variables $\left(\mathrm{W} \mathrm{m}^{-2}\right)$} \\
\hline $\mathrm{SW}_{\text {in }}$ & 117 & 131 & 142 \\
\hline $\mathrm{SW}_{\text {out }}$ & -73 & -94 & -110 \\
\hline $\mathrm{SW}_{\text {net }}$ & 45 & 36 & 32 \\
\hline $\mathrm{LW}_{\text {in }}$ & 241 & 227 & 222 \\
\hline $\mathrm{LW}_{\text {out }}$ & -280 & -269 & -260 \\
\hline $\mathrm{LW}_{\text {net }}$ & -39 & -42 & -38 \\
\hline$R_{\text {net }}$ & 6 & -6 & -6 \\
\hline SHF & 38 & 26 & 18 \\
\hline LHF & -4 & -2 & -4 \\
\hline$G$ & 2 & 3 & 3 \\
\hline$M$ & 41 & 20 & 11 \\
\hline
\end{tabular}

* September 2007-August 2008, June and July 2010 are missing at S6.

model characteristics; for a more detailed model description, the reader is referred to Van den Broeke (2004, 2008a, b, 2009b).

As input the SEB model uses hourly values of $z_{0}$, (corrected) single-level measurements of wind speed, temperature and humidity, $\mathrm{SW}_{\mathrm{in}}, \mathrm{SW}_{\text {out }}$ and $\mathrm{LW}_{\mathrm{in}}$. The scalar roughness lengths for heat $\left(z_{h}\right)$ and moisture $\left(z_{q}\right)$ are calculated using the expressions of Andreas (1987), including the adjustments for very rough ice surfaces proposed by Smeets and Van den Broeke (2008b). The SEB model solves Eq. (1) to obtain surface temperature $T_{\mathrm{s}}$, using bisection and nested iterative procedures for the stability corrections in the turbulent heat flux calculations, assuming the surface to be saturated with respect to ice (or water when the surface is melting). If $T_{\mathrm{S}}$ exceeds the melting point, it is reset to $273.15 \mathrm{~K}$ and all remaining energy is used for melt. This way of working assumes a closed energy balance and therewith differs from Van den Broeke (2008a, 2009b), who did not require melt rate to be quantified and therefore could use "observed" $T_{\mathrm{S}}$ (from $\mathrm{LW}_{\text {out }}$ ) to calculate the radiation balance and turbulent fluxes.

Equation (1) assumes all energy to be absorbed at the surface, neglecting penetration of shortwave radiation to levels below the surface. This may be justified for fine-grained dry snow, but not for bare glacier ice. When ice is exposed at the surface at S5 and S6, the model of Brandt and Warren (1993) is used to calculate the subsurface shortwave radiation flux. This model is based on Mie scattering in a medium of perfectly stacked spherical particles with $2.5 \mathrm{~mm}$ diameter combined with the two-stream approach of Schlatter (1972), using 118 wavelength bands to account for the highly wavelength-dependent absorption properties of ice. We correct the incoming shortwave spectrum for atmospheric mass and the presence of clouds, the latter 


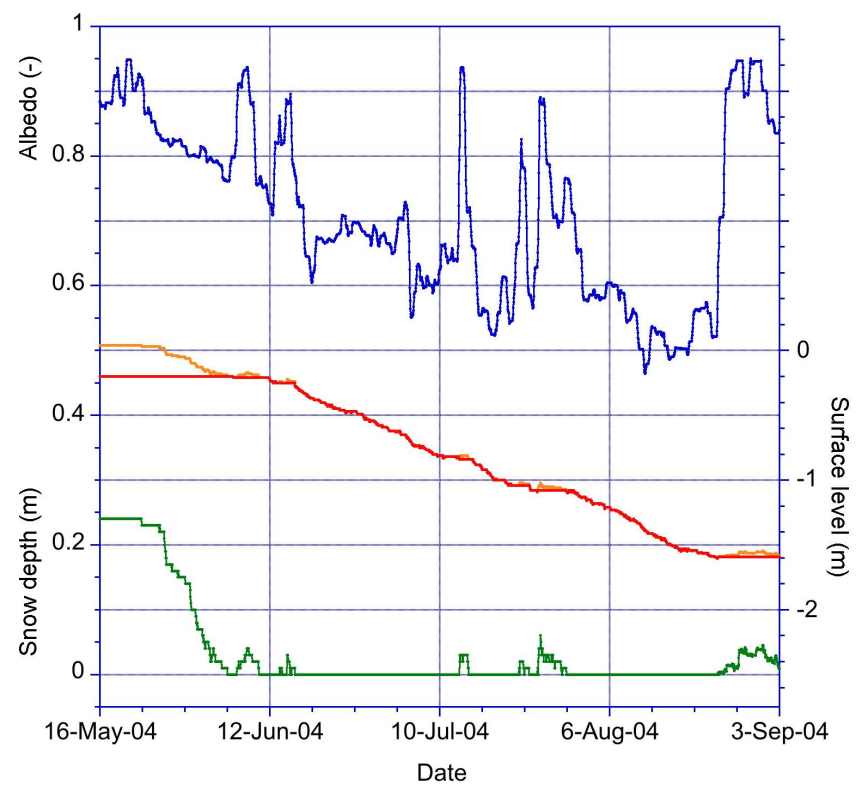

Fig. 2. Albedo (blue line, based on 24-h running mean shortwave fluxes), snow surface (orange line), reconstructed ice horizon (red line) and associated snow depth (green line) derived from sonic height ranger measurements for S6, summer 2004.

parameterized using the expressions of Kuipers Munneke et al. (2010). The radiation grid has $1 \mathrm{~mm}$ resolution to a depth of $5 \mathrm{~m}$, after which radiative heating is interpolated to the coarser temperature grid.

\section{Results}

\subsection{Model evaluation for melting and non-melting conditions}

The modelled SEB must be evaluated separately for melting and non-melting conditions. When the surface is not melting, modelled values of surface temperature $T_{\mathrm{s}}$ can be compared to "observed" values derived from $\mathrm{LW}_{\text {out }}$. Assuming a constant, unit longwave emissivity of the snow/ice surface, the results for observed and modelled hourly and monthly mean $T_{\mathrm{S}}$ are presented in Fig. 3a-c. The model performs well, with an average difference for hourly values between $-0.28 \mathrm{~K}$ at $\mathrm{S} 5$ and $0.34 \mathrm{~K}$ at $\mathrm{S} 9$. The RMSE decreases from $1.26 \mathrm{~K}$ at S5 to $0.97 \mathrm{~K}$ at $\mathrm{S} 9$. The better performance of the model in the higher ablation zone is probably associated with the smaller summer ablation, resulting in smaller mast displacement and tilt, and hence smaller corrections for the shortwave radiation measurements.

During melt conditions, $T_{\mathrm{S}}$ is constant and therefore not a useful variable to evaluate the SEB model. Instead we compare observed and modelled melt rates for ice, which has a well-known density $\left(910 \mathrm{~kg} \mathrm{~m}^{-3}\right)$, thus enabling a conversion from height change (as measured by the sonic height
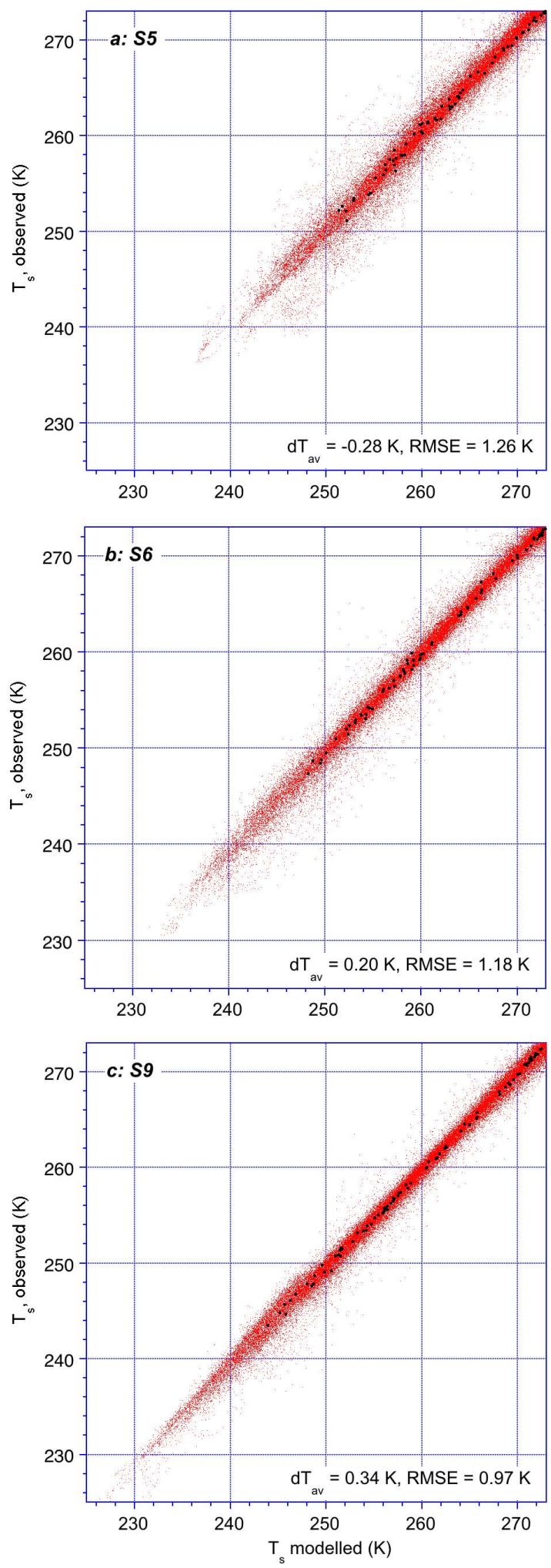

Fig. 3. Observed vs modelled surface temperature for hourly (red dots) and monthly averages (black dots) at S5 (a), S6 (b) and S9 (c). $d T_{\mathrm{av}}$ is average difference, RMSE is Root Mean Squared Error. 

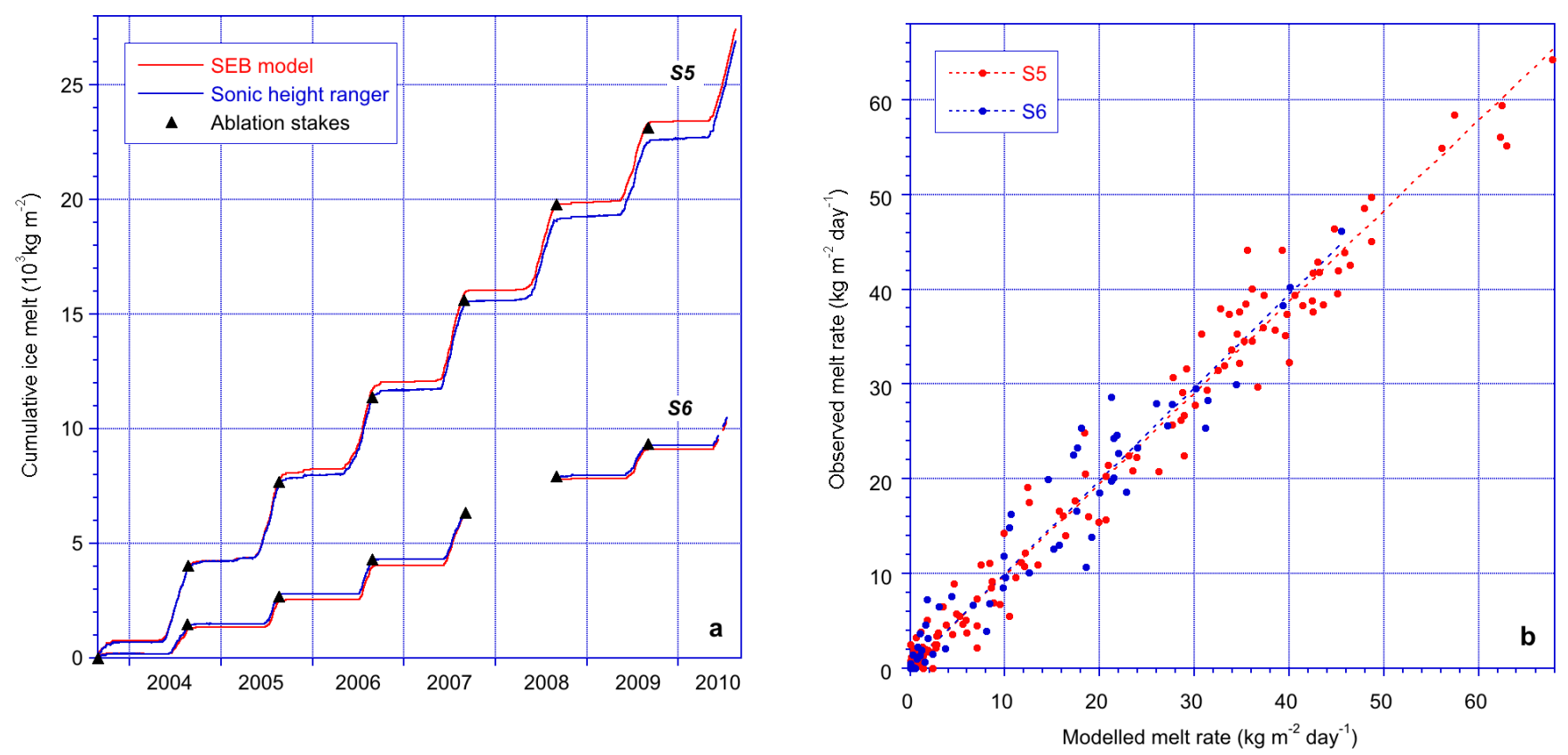

Fig. 4. (a) Observed (blue line) versus modelled (red line) cumulative ice ablation at S5 and S6. Cumulative ice melt from annual stake measurements are indicated by triangles. (b) Observed versus modelled 10-day average ice melt rates at S5 (red dots) and S6 (blue dots). The dashed lines are linear regressions on the data.

ranger) to mass change and hence (modelled) melt energy. This does not work for S9, where the surface consists of snow/firn with unknown density, but it works well for S5 and S6, where ice is frequently present at the surface and can easily be detected (Fig. 2). Figure 4a shows that cumulative ice melt measured by the sonic height rangers at S5 $\left(26.9 \times 10^{3} \mathrm{~kg} \mathrm{~m}^{-2}\right)$ and $\mathrm{S} 6\left(10.5 \times 10^{3} \mathrm{~kg} \mathrm{~m}^{-2}\right)$ is matched by the SEB model to within $1.9 \%$ (S5) and $1.6 \%$ (S6). The difference between the sonic height ranger and the ablation stake measurements (triangles in Fig. 4a) is an indication of the observational uncertainty, arising from instrumental error, from the fact that the observations are not performed at exactly the same location but especially from the fact that stake measurements are not very accurate in the first place. At S5, modelled cumulative ice ablation follows the stake measurements better than the continuous track of the sonic height ranger. At both sites, observed and modelled cumulative melt agree to within the observational uncertainty. A stricter evaluation of the SEB model is to compare observed and modelled ice melt over shorter periods (Fig. 4b). A 10-day period is chosen, to reduce the measurement noise of the sonic height ranger to a level that enables a meaningful comparison. Again, agreement between modelled and observed ice melt is very good at both sites (S5: $r=0.99$, slope $=0.96$, RMSE $=2.1 \mathrm{~kg} \mathrm{~m}^{-2} \mathrm{day}^{-1}$; S6: $r=0.98$, slope $=0.98, \operatorname{RMSE}=1.7 \mathrm{~kg} \mathrm{~m}^{-2} \mathrm{day}^{-1}$ ).

We conclude that during melting conditions, the SEB model is capable of reliably simulating interannual and intraseasonal melt rate variability. During non-melting condi- tions, the SEB model accurately simulates the surface temperature. These results lend credibility to the modelled SEB components.

\subsection{Average seasonal cycle of the SEB}

Table 2 shows some climate and energy balance statistics. The lapse rate of $2 \mathrm{~m}$ temperature is $7.4 \mathrm{~K} \mathrm{~km}^{-1}$ between S5 and $\mathrm{S} 6$ and $5.8 \mathrm{~K} \mathrm{~km}^{-1}$ between $\mathrm{S} 6$ and $\mathrm{S} 9$. The stronger temperature decrease near the margin reflects the effect of the warm summertime tundra on the temperature at S5. The relative humidity increases towards higher elevation, but specific humidity decreases owing to lower temperatures that limit the atmospheric moisture content. Wind speed becomes significantly larger towards the interior, which is partly caused by the smaller momentum roughness, and partly by the greater influence of the upper level winds in the Greenland interior (Van Angelen et al., 2011). The thinner atmosphere at $\mathrm{S} 9$ transmits more shortwave radiation, but as the average surface albedo is also higher, and the latter effect dominates, net shortwave radiation $\left(\mathrm{SW}_{\text {net }}\right)$ decreases from $\mathrm{S} 5$ to $\mathrm{S} 9$. As a result of the warm air from the tundra during summer, the flux of sensible heat (SHF) towards the surface is also greatest at $\mathrm{S} 5$. The gradients in these two SEB components $\left(\mathrm{SW}_{\text {net }}\right.$ and SHF) are the main reason for the exponential increase of melt energy when going from S9 to S5.

Figure 5 displays the average seasonal cycle of monthly melt frequency at the AWS sites, based on hourly data. The error bars represent one standard deviation for the monthly 


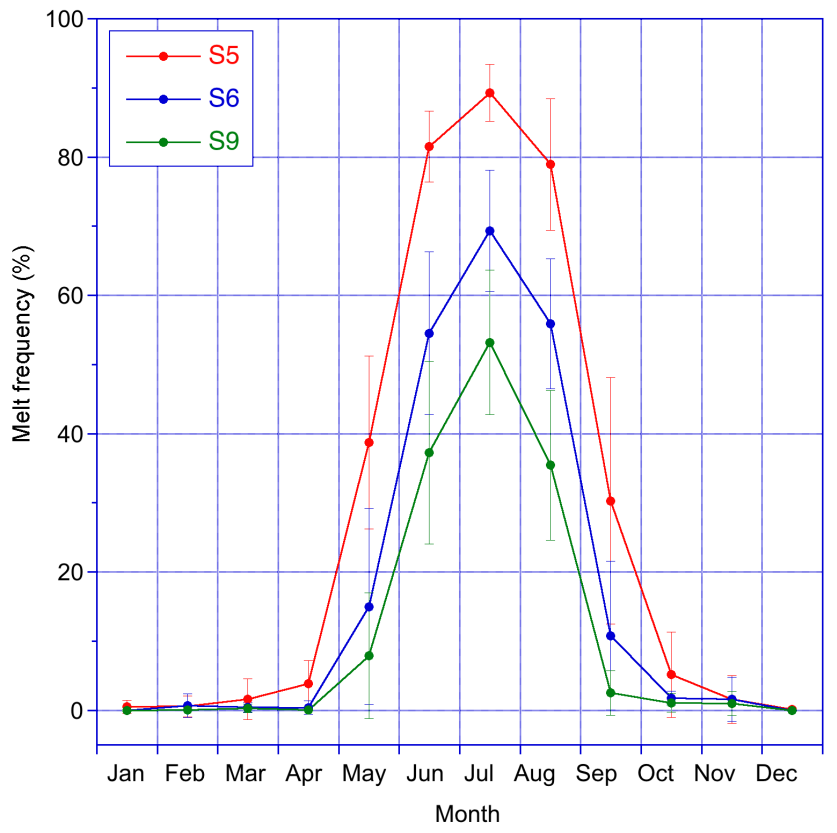

Fig. 5. Average seasonal cycle of melt frequency, based on hourly data, at S5 (red line), S6 (blue line) and S9 (green line). Error bars indicate standard deviation for the 7-yr period.

means. Annual average modelled melt frequencies are $28 \%$ at S5, $16 \%$ at S6 and $12 \%$ at S9. At S5, melt may occur in any month of the year, even occasionally in mid-winter. In the lower ablation zone the melt season usually starts at the end of April, with an average melt frequency of several \%. May marks the start of the ablation season in the middle to higher ablation zone, with melt frequencies of $15 \%$ at S6 to $8 \%$ at S9. Melt frequency peaks in July at all AWS, and varies from $52 \%$ at S9, $68 \%$ at S6 and $88 \%$ at S5. September is still a significant melt month at S5 and S6, with average melt frequencies of 30 and $10 \%$, respectively.

Figure 6a shows the average seasonal cycle of albedo at the three sites. The error bars represent one standard deviation for the monthly means, and for clarity the seasonal cycle of the standard deviation is plotted separately in Fig. 6b. The shape of the seasonal cycle at S5 differs significantly from that at S6 and S9. Winter accumulation is small at S5, owing to significant wintertime snowdrift sublimation and the infilling with snow of the abundant crevasses. In late winter and spring, the surface at S5 consists of a mix of bare ice and snow, which explains the intermediate albedo values and very large standard deviations in the period February-April. Persistent melt causes the relatively dark glacier ice to be exposed throughout summer, leading to low albedo values and low interannual variability. At S6, the surface is covered by snow until May, but melt may occur in April and May, resulting in an increase in the standard deviation. June is a transition month. In July and August, ice is exposed at S6 and the albedo reaches its minimum, but summer snowfalls (see
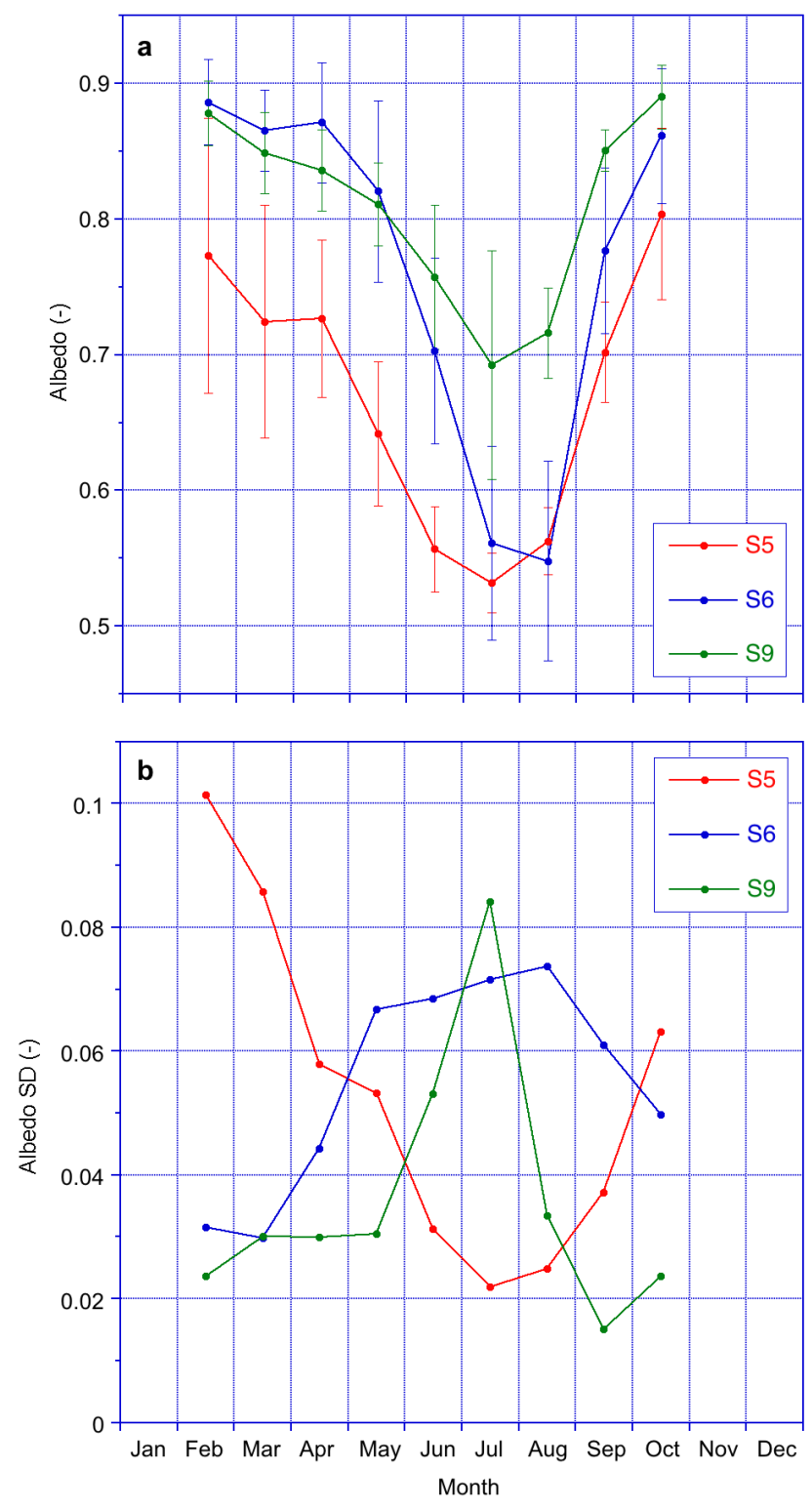

Fig. 6. Average seasonal cycle of albedo (a) (error bars indicate standard deviation for the 7-yr period) and average seasonal cycle of the albedo standard deviation (SD) (b).

Fig. 2) keep the interannual variability high. At S9, glacier ice is not exposed, and the seasonal cycle in albedo reflects the progressive metamorphism of the firn under the influence of melt. Interannual variability peaks in July, caused by summer snowfalls.

Figure 7a-c shows the average seasonal cycle of SEB components at the three AWS sites. We have integrated the energy fluxes from the surface to the lowest ice level in the model, so that a single value can be presented for $\mathrm{SW}_{\text {net }}, G$ and $M$. The error bars represent one standard deviation for the monthly means. The amplitude of the main forcing component of the seasonal cycle in the SEB, $\mathrm{SW}_{\text {net }}$, on average 

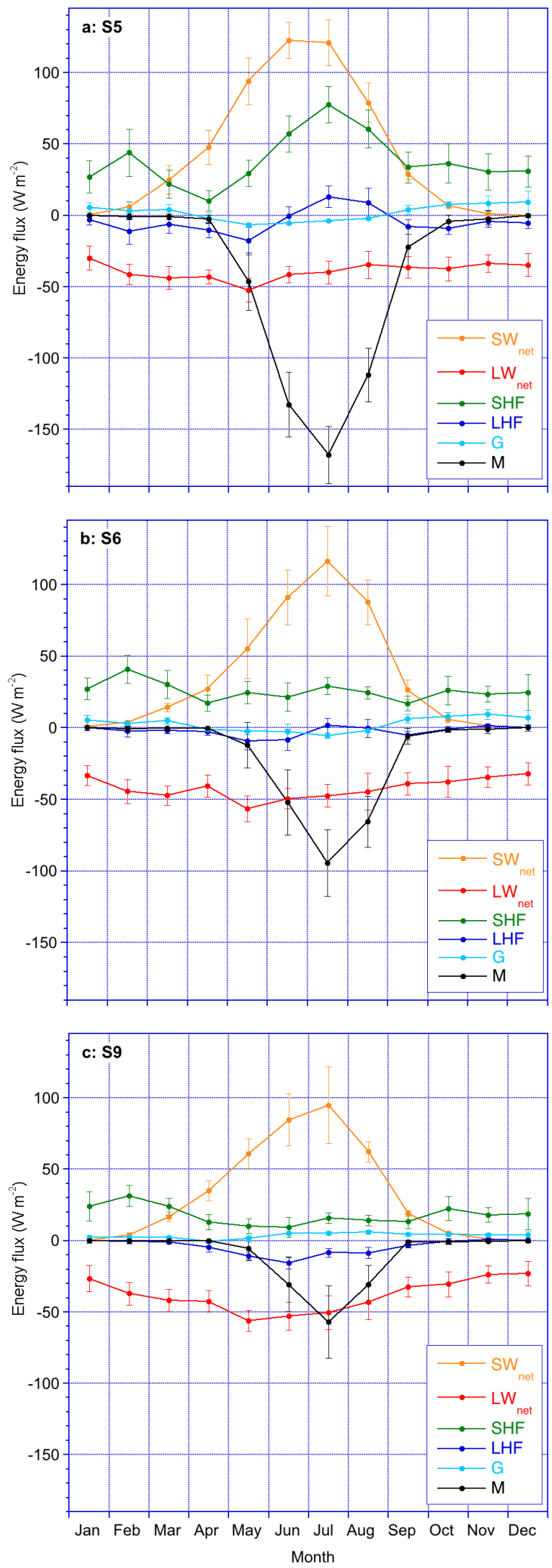

Fig. 7. Average seasonal cycle of SEB components at S5 (a), S6 (b) and S9 (c). Error bars indicate standard deviation for the 7-yr period. decreases towards higher elevations, a result of the higher average surface albedo. The shape of the seasonal SEB cycle at $\mathrm{S} 5$ differs significantly from that at $\mathrm{S} 6$ and $\mathrm{S} 9$, as a result of the different seasonal cycle of albedo. At S5, SW net is distributed rather symmetrically around the summer solstice, while at S6 and S9, the more gradual decrease of albedo causes the seasonal cycle of $\mathrm{SW}_{\text {net }}$ to be less symmetric, with a slow increase towards a peak in July and a rapid decrease in fall.

Being situated on the protruding tongue of Russell glacier, the SEB at S5 is influenced by the thermal characteristics of the surrounding ice-free tundra. Especially in July, when most of the moisture has evaporated from the upper tundra layers, $2 \mathrm{~m}$ temperatures over the tundra may reach $15-20^{\circ} \mathrm{C}$ during sunny conditions (Van den Broeke et al., 1994). The associated horizontal temperature gradient sets up a pressure perturbation that is favourable for the formation of strong barrier winds that blow from south to north along the largescale direction of the ice sheet margin (Van den Broeke and Gallée, 1996). This enhances turbulent heat exchange between the ambient atmosphere and the melting ice surface, resulting in significantly positive values of SHF and LHF at S5 (Fig. 7a). SHF shows a double maximum, owing to katabatic wind forcing that prevails in the absence of barrier winds both in summer and winter. The July peaks in SHF and LHF shift the melt peak away from the maximum in $\mathrm{SW}_{\text {net }}$. Another effect of the presence of warm tundra air is to enhance $\mathrm{LW}_{\text {in }}$ through higher ambient temperatures and moisture in the low atmosphere. This results in less negative values of $\mathrm{LW}_{\text {net }}$, as $\mathrm{LW}_{\text {out }}$ is constant under melting conditions. The effect on $\mathrm{LW}_{\text {net }}$ at $\mathrm{S} 5$ is a difference with $\mathrm{S} 6$ and S9 of $10-15 \mathrm{~W} \mathrm{~m}^{-2}$, representing a significant $10 \%$ of the available melt energy at the ice sheet margin.

Higher on the ice sheet at S6 and S9, the temperature and moisture contrasts between ambient atmosphere and (melting) ice surface are less pronounced, resulting in smaller summertime values of SHF, LHF and $\mathrm{LW}_{\text {net. }}$ At S9, the moisture gradient is reversed and LHF becomes negative and therewith compensates a large part of SHF, a well-known summer phenomenon close to the equilibrium line (Ambach, 1977; Henneken et al., 2004).

\subsection{Interannual variability}

The good performance of the SEB model and the reasonable length of the time series enables us to use the AWS data for a preliminary study of factors driving interannual melt variability in this part of the GrIS. The error bars in Fig. 5 indicate that interannual variability of midsummer melt frequency increases towards the higher ablation zone. For instance, S9 melt frequencies for June vary from $18 \%$ in 2006 to $56 \%$ in 2007 . The years 2007 and 2010 stand out as highfrequency melt years, with a July melt frequency at S9 of almost $70 \%$. In contrast, lower in the ablation zone at S5, the mid-summer melt frequency is remarkably stable from year 

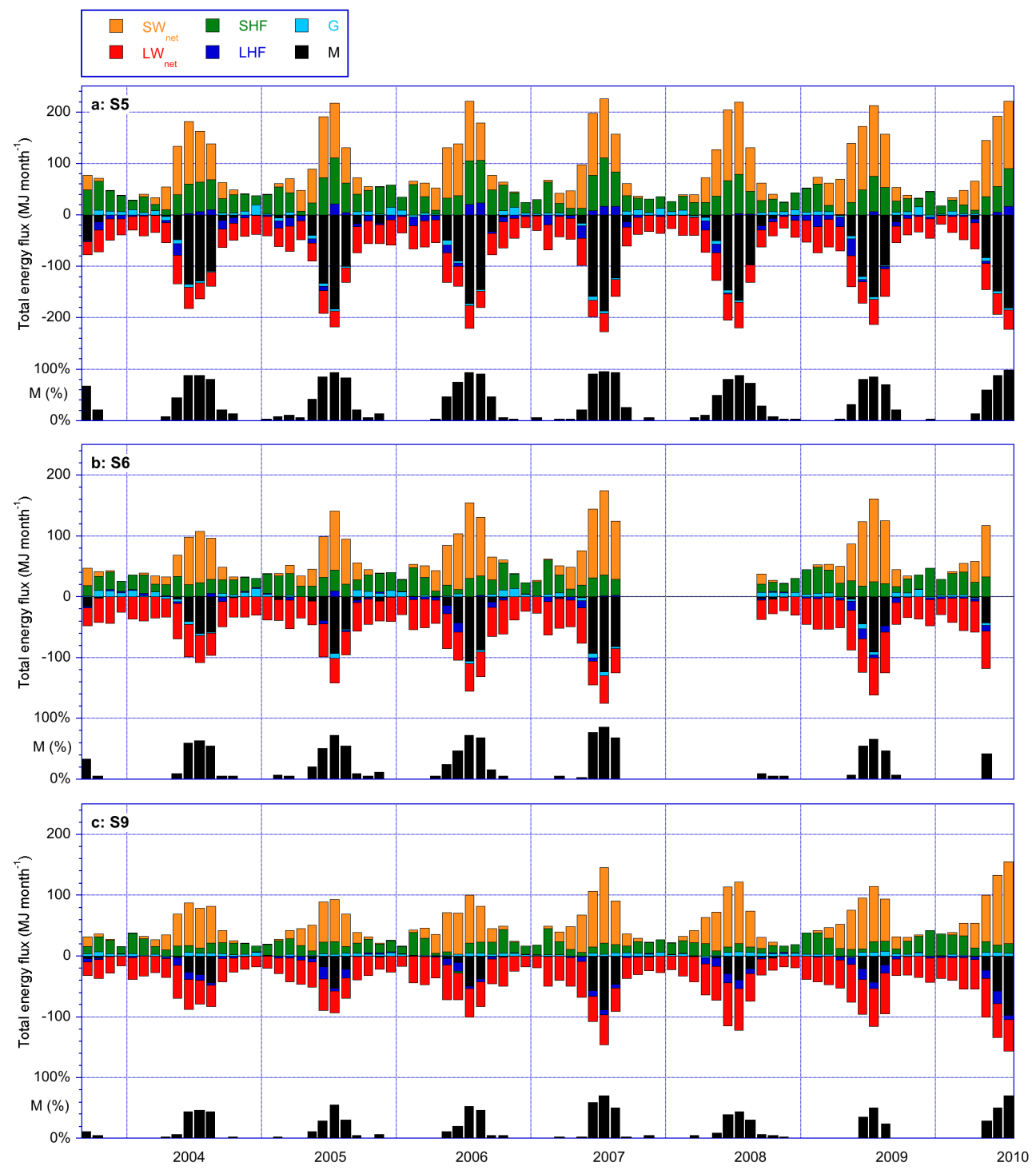

Fig. 8. Monthly mean SEB components and melt frequency (\%) at S5 (a), S6 (b) and S9 (c).

to year, with July values ranging from $83-93 \%$. Here, the variability is largest in the beginning (May) and end (September) of the ablation season. For instance, September 2003 had a $65 \%$ melt frequency at S5, while it was only $18 \%$ in 2004 and 2009.

Figure $8 \mathrm{a}-\mathrm{c}$ shows the time series of monthly mean SEB components at the three AWS sites, including melt frequency (black bars). At S5, the onset and evolution of the ablation season in terms of melt frequency is comparable from year to year. At S6 and S9, there is considerably more interannual variability. For instance, the summers of 2007 and 2010 (until July only) clearly stand out as anomalous, with high melt rates.

Figure 9 shows the cumulative energy sources for melt at the three sites, based on monthly totals and expressed in
$\mathrm{GJ} \mathrm{m}^{-2}$. The anomalous melt seasons of 2007 and 2010 stand out especially in the high ablation zone (S9). At all three sites, $\mathrm{SW}_{\text {net }}$ is the main energy source for melt, followed by SHF. LHF represents a small energy source for melt at S5, is zero at S6 and a small energy sink at S9. The subsurface heat flux is an energy sink at S5 and S6: the impermeable ice does not allow meltwater to refreeze at depth, maintaining the temperature gradient between the upper and lower ice layers; in combination with the large heat conductivity of ice, this efficiently transports heat towards greater depths. At S9, meltwater penetration and refreezing bring the snowpack at the melting point over a considerable depth. In combination with the smaller heat conductivity of snow, this means that $G$ becomes small during melt. At all sites, $\mathrm{LW}_{\text {net }}$ is the main heat sink during melt. 

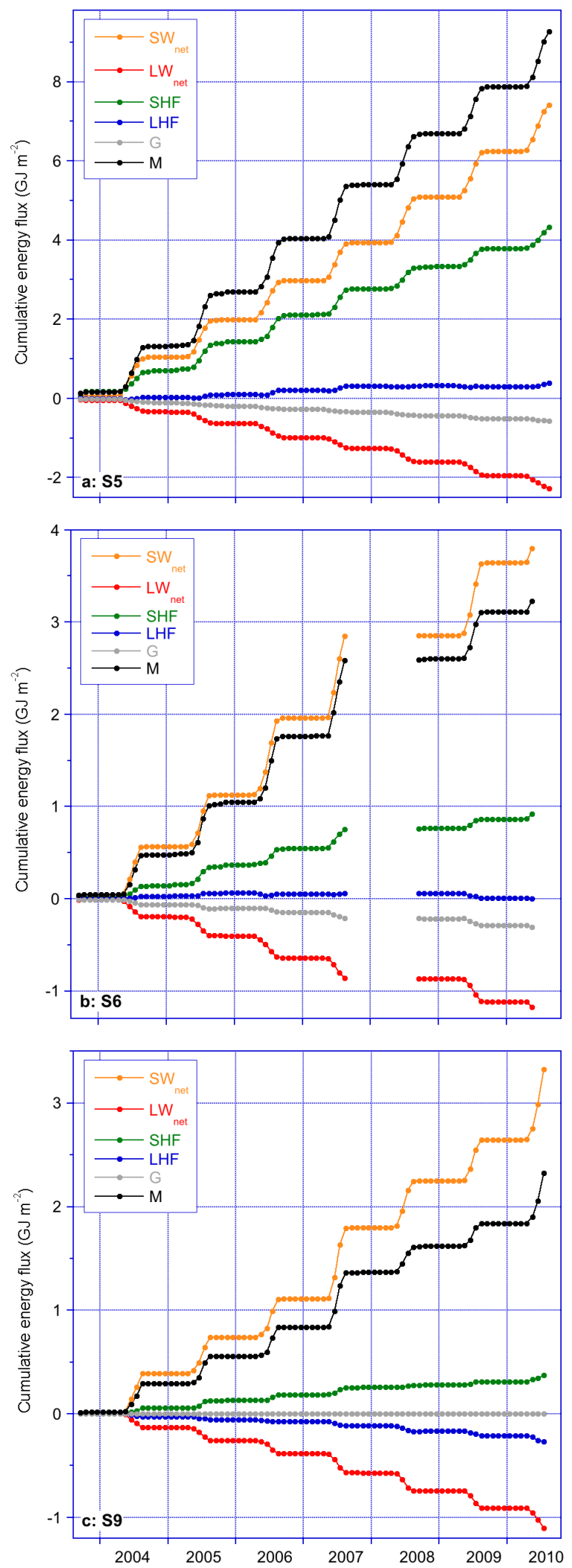

Fig. 9. Cumulative energy fluxes $\left(10^{3} \mathrm{MJ} \mathrm{m}^{-2}\right)$ during melt for S5 (a), S6 (b) and S9 (c).

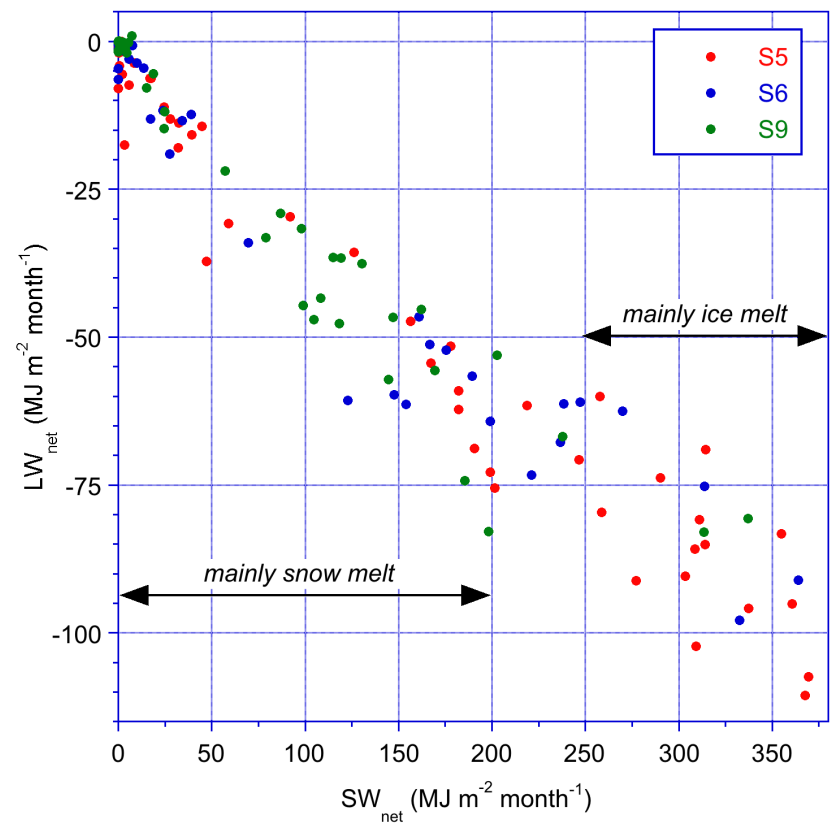

Fig. 10. Correlation of monthly mean net longwave and net shortwave radiation during melt for S5 (red dots), S6 (blue dots) and S9 (green dots).

At $\mathrm{S} 6$ and S9, cumulative $\mathrm{SW}_{\text {net }}$ values exceed total cumulative melt energy. This is possible, because $\mathrm{SW}_{\text {net }}$ and $\mathrm{LW}_{\text {net }}$ are themselves highly negatively correlated for monthly totals (Fig. 10). This correlation reflects the fact that clear skies on one hand lead to high monthly totals for $\mathrm{SW}_{\text {net }}$, but on the other hand also limit downward atmospheric radiation $\left(\mathrm{LW}_{\text {in }}\right)$, while $\mathrm{LW}_{\text {out }}$ is constant. The shift in slope at high values of $\mathrm{SW}_{\text {net }}$ in Fig. 10 is caused by the albedo difference between melting snow $(\approx 0.7)$ and ice $(\approx 0.55)$.

Figure 11a summarizes the average contribution of the SEB components to the melt energy as a function of distance to the ice margin. It confirms that, owing to the negative correlation of $\mathrm{SW}_{\text {net }}$ with $\mathrm{LW}_{\text {net }}$, the contribution of cumulative $R_{\text {net }}$ to melt remains smaller than unity throughout the ablation zone. In the lower ablation zone, the combined contributions of SHF and LHF to melt are similar to $R_{\text {net }}$. In the higher ablation zone, the contributions of SHF and LHF to melt approximately cancel, and $R_{\text {net }}$ is the primary energy source for melt. As a heat sink/source for melt, the subsurface heat flux $G$ is generally small.

\subsection{The role of large scale and regional circulations}

The fact that $\mathrm{SW}_{\text {net }}\left(R_{\text {net }}\right)$ is the main energy source for melt does not necessarily mean that interannual variations in $\mathrm{SW}_{\text {net }}$ also explain most of the year-to-year variations in melt. To explore this further, we linearly regressed anomalies of monthly cumulative SEB components during melt onto anomalies of monthly cumulative melt energy. Figure $11 \mathrm{~b}$ 

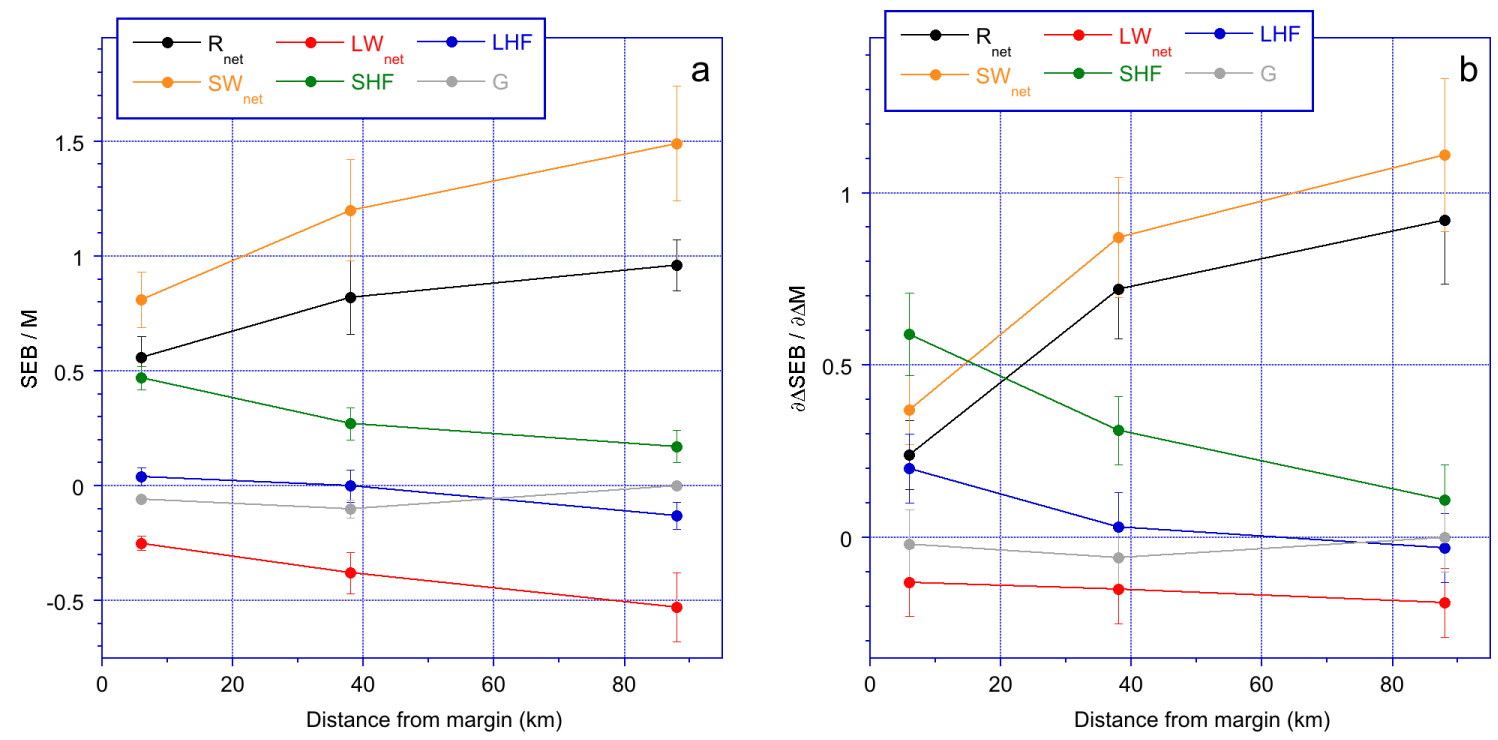

Fig. 11. Variation with distance from ice margin of (a): fraction of total melt energy provided by SEB components (error bar indicate standard deviation from year to year) and (b): regression slope of cumulative monthly SEB energy components with cumulative monthly melt (error bar represents standard deviation from regression performed on subsets of the data).

shows the slope of the regressions ( $\partial \Delta \mathrm{SEB} / \partial \Delta M$, where $\triangle$ SEB indicates the anomaly of an SEB component from the mean) as a function of distance to the ice margin. The error bars are based on regressions performed on subsets of the data, with a minimum of 0.1 . At $\mathrm{S} 6$ and $\mathrm{S} 9, \partial \Delta \mathrm{SW}_{\text {net }} / \partial \Delta M$ dominates, indicating that interannual variability in $\mathrm{SW}_{\text {net }}$ explains most of the variability in melt. This is indicative of an active melt-albedo feedback, i.e. the fact that the albedo of melting snow is considerably lower than that of dry snow. At both sites, SHF also explains part of the melt variability, while $\partial \Delta \mathrm{LHF} / \partial M$ and $\partial \Delta G_{\mathrm{s}} / \partial M$ are not significantly different from zero. At S5, $\partial \Delta \mathrm{SHF} / \partial \Delta M$ dominates, indicating that changes in SHF are the best predictor for melt variability close to the ice margin $(r=0.59$, explained variance $35 \%)$. At $\mathrm{S} 5, \partial \Delta \mathrm{LHF} / \partial \Delta M$ is also significant and equally large as $\partial \Delta R_{\text {net }} / \partial \Delta M$. This follows from the fact that the surface at S5 is snow-free for most of the summer. As a result, the surface albedo is more or less constant and the melt-albedo feedback is not active.

Moreover, as explained in the previous sections, S5 is under the direct influence of warmer air masses to the west and south of the ice sheet, which can be mixed downward to the ice surface by regional or large scale circulation. A pronounced regional circulation develops in summer during sunny weather with on-ice directed large-scale flow, creating a sharp temperature contrast at the ice sheet margin between the warm tundra air and the cold ice sheet air. This results in the formation of a thermally driven north-south directed low-level jet, the so-called barrier wind (Van den Broeke and Gallée, 1996). The associated strong wind shear and temperature gradients strongly enhance SHF, LHF and hence melt near the ice sheet margin. Alternatively, synoptic systems may advect warm air from lower latitudes to the marginal ice sheet. To illustrate the impact of regional and large scale circulation on the SEB in the ablation zone, Fig. 12 shows hourly values of $10 \mathrm{~m}$ wind speed (a), $2 \mathrm{~m}$ and surface temperature (b) and SEB components at S5 for a two-month period in 2005. During this period, six high wind speed events can be distinguished, numbered I-VI in Fig. 12a. These events are all associated with high $2 \mathrm{~m}$ temperatures, indicating the downward mixing of warm air, and high SHF values, generally in excess of $100 \mathrm{~W} \mathrm{~m}^{-2}$, promoting strong melting. LHF values generally remain below $50 \mathrm{~W} \mathrm{~m}^{-2}$. Further on the ice sheet, at S6 and S9, the impact of these events on the turbulent fluxes is much smaller owing to the smaller air-to-ice sheet temperature gradients (not shown). As the occurrence of these events is highly variable from year to year, they explain a large part of the melt variability, in spite of the fact that these SEB components contribute less than $50 \%$ to the total seasonal melt energy. This is as important as it is interesting, because in a future warmer climate, when the ice sheet retreats on land and more ice-free land is exposed, the SEB and associated melt climate as presently observed at S5, including the occurrence of barrier winds, will become representative for the entire marginal ice sheet, including those parts that are currently adjacent to the ocean.

\section{Summary and conclusions}

We used seven years of automatic weather station data from the ablation zone in west Greenland to drive a surface energy balance (SEB) model that calculates SEB components, surface temperature and melt rate. Modelled surface 

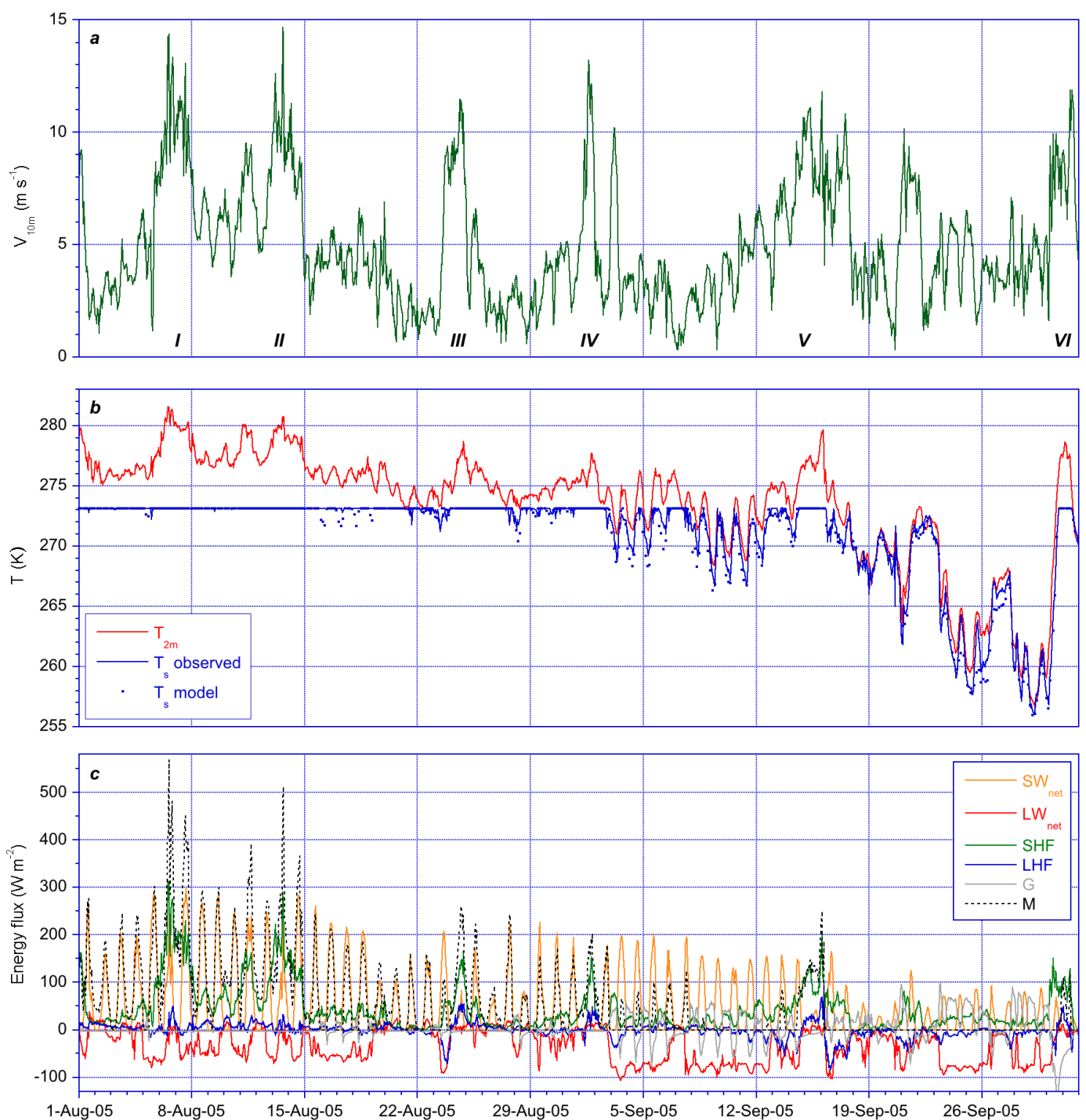

Fig. 12. Hourly averages at S5 for the period 1 August-30 September 2005 of (a) $10 \mathrm{~m}$ wind speed, (b) $2 \mathrm{~m}$ temperature and observed (lines) and modelled (dots) surface temperature $T_{\mathrm{S}}$, and (c) modelled surface energy balance components.

temperatures and ice melt rates compare very well to observations. Melt frequency in summer ranges from $80-95 \%$ in the lower ablation zone to $35-55 \%$ close to the equilibrium line. The average seasonal cycle of melt as well as interannual melt variability is mainly driven by absorption of shortwave radiation; an exception is the lower ablation zone, where the turbulent fluxes of sensible and latent heat contribute significantly to the melt energy, and are also the most important SEB components explaining interannual melt variability. Strong turbulent exchange is maintained by barrier winds, a low level jet along the ice sheet margin that is forced by thermal differences between the tundra and the ice sheet. This melt regime, which is typical for ice caps surrounded by ice free land in more temperate climate regions, is expected to become more important in Greenland in a warmer future, when the ice sheet retreats on land. Unfortunately, the AWS observations used in this study are only locally representative and their time series too short to infer trends in the melt regime. An important question therefore remains how representative these observations are for the Greenland ice sheet as a whole, and whether the Greenland melt regime has undergone significant changes in recent decades. This can only be addressed using output of a regional atmospheric climate model (Ettema et al., 2010a, b), and will be explored in a forthcoming study.

Acknowledgements. This work is funded by Utrecht University and the Netherlands Arctic Program (NAP) of the Netherlands Organisation of Scientific Research, section Earth and Life Sciences (NWO/ALW).

Edited by: E. Hanna 


\section{References}

Ambach, W.: Untersuchungen zum Energieumsatz in der Akkumulationszone des Grönländischen Inlandeises, Meddelelser om Grønland 187-7, Bianco Lunos Bogtrykkeri A/S, Copenhagen, 1977.

Andreas, E. L.: A theory for the scalar roughness and the scalar transfer coefficients over snow and sea ice, Bound.-Lay. Meteorol., 38, 159-184, 1987.

Bamber, J. L., Ekholm, S., and Krabill, W. B.: A new, highresolution digital elevation model of Greenland fully validated with airborne altimeter data, J. Geophys. Res., 106, 6733-6745, 2001.

Bøggild, C. E., Reeh, N., and Oerter, H.: Modelling ablation and mass-balance sensitivity to climate change of Storstrømmen, northeast Greenland, Global Planet. Change, 9, 79-90, 1994.

Box, J. E. and Cohen, A. E.: Upper-air temperatures around Greenland. 1964-2005, Geophys. Res. Lett., 33, L12706, doi:10.1029/2006GL025723, 2006.

Box, J. E. and Ski, K.: Remote sounding of Greenland supraglacial melt lakes. implications for subglacial hydraulics, J. Glaciol., 53, 257-265, 2007.

Brandt, R. E. and Warren, S. G.: Solar heating rates and temperature profiles in Antarctic snow and ice, J. Glaciol., 39, 99-110, 1993.

Ettema, J., van den Broeke, M. R., van Meijgaard, E., van de Berg, W. J., Bamber, J. L., Box, J. E., and Bales, R. C.: Higher surface mass balance of the Greenland ice sheet revealed by highresolution climate modeling, Geophys. Res. Lett., 36, L12501, doi:10.1029/2009GL038110, 2009.

Ettema, J., van den Broeke, M. R., van Meijgaard, E., van de Berg, W. J., Box, J. E., and Steffen, K.: Climate of the Greenland ice sheet using a high-resolution climate model - Part 1: Evaluation, The Cryosphere, 4, 511-527, doi:10.5194/tc-4-511-2010, 2010a.

Ettema, J., van den Broeke, M. R., van Meijgaard, E., and van de Berg, W. J.: Climate of the Greenland ice sheet using a highresolution climate model - Part 2: Near-surface climate and energy balance, The Cryosphere, 4, 529-544, doi:10.5194/tc-4529-2010, 2010b.

Fettweis, X.: Reconstruction of the 1979-2006 Greenland ice sheet surface mass balance using the regional climate model MAR, The Cryosphere, 1, 21-40, doi:10.5194/tc-1-21-2007, 2007.

Fettweis, X., Mabille, G., Erpicum, M., Nicolay, S., and van den Broeke, M. R.: The 1958-2009 Greenland ice sheet surface melt and the mid-tropospheric atmospheric circulation, Clim. Dynam., 36, 139-159, doi:10.1007/s00382-010-0772-8, 2010.

Greuell, W. G. and Konzelmann, T.: Numerical modelling of the energy balance and the englacial temperature of the Greenland Ice Sheet. Calculations for the ETH-Camp location (West Greenland, 1155 m a.s.1.), Global Planet. Change, 9, 91-114, 1994.

Hanna, E., Huybrechts, P., Steffen, K., Cappelen, J., Huff, R., Shuman, C., Irvine-Fynn, T., Wise, S., and Griffiths, M.: Increased Runoff from Melt from the Greenland Ice Sheet. A Response to Global Warming, J. Climate, 21, 331-341, 2008.

Heinemann, G.: The KABEG'97 field experiment. An aircraftbased study of the katabatic wind dynamics over the Greenlandic ice sheet, Bound.-Lay. Meteorol., 93, 75-116, 1999.

Henneken, E. A. C., Bink, N. J., Vugts, H. F., Cannemeijer, F., and Meesters, A. G. C. A.: A case study of the daily energy balance near the equilibrium line on the Greenland ice sheet, Global Planet. Change, 9, 69-78, 1994.
Joughin, I., Das, S. B., King, M. A., Smith, B. E., Howat, I. M., and Moon, T.: Seasonal speedup along the western flank of the Greenland ice sheet, Science, 320, 781-783, 2008.

Konzelmann, T. and Braithwaite, R. J.: Variations of ablation, albedo and energy balance at the margin of the Greenland ice sheet, Kronprins Christian Land, eastern North Greenland, J. Glaciol., 41, 174-182, 1995.

Kuipers Munneke, P., Reijmer, C. H., and van den Broeke, M. R.: Assessing the retrieval of cloud properties from radiation measurements over snow and ice, Int. J. Climatol., 31, 756-769, doi:10.1002/joc.2114, 2010.

Oerlemans, J. and Vugts, H. F.: A Meteorological Experiment in the Melting Zone of the Greenland Ice Sheet, B. Am. Meteorol. Soc., 74, 355-365, 1993.

Schlatter, T. W.: The local surface energy balance and subsurface temperature regime in Antarctica, J. Appl. Meteorol., 11, 10481062, 1972.

Schoof, C.: Ice-sheet acceleration driven by melt supply variability, Nature, 468, 803-806, doi:10.1038/nature09618, 2010.

Shepherd, A., Hubbard, A., Nienow, P., King, M., McMillan, M., and Joughin, I.: Greenland ice sheet motion coupled with daily melting in late summer, Geophys. Res. Lett., 36, L01501, doi:10.1029/2008GL035758, 2009.

Smeets, C. J. P. P. and van den Broeke, M. R.: Temporal and spatial variation of momentum roughness length in the ablation zone of the Greenland ice sheet, Bound.-Lay. Meteorol., 128, 315-338, 2008a.

Smeets, C. J. P. P. and van den Broeke, M. R.: The parameterisation of scalar transfer over rough ice surfaces, Bound.-Lay. Meteorol., 128, 339-355, 2008b.

Steffen, K. and Box, J. E.: Surface climatology of the Greenland ice sheet. Greenland Climate Network 1995-1999, J. Geophys. Res., 106(D24), 33951-33964, 2001.

Tedesco, M., Fettweis, X., van den Broeke, M. R., van de Wal, R. S. W., and Smeets, P.: Extreme Snowmelt in Northern Greenland During Summer 2008, Eos Trans. AGU, 89, p. 391, doi:10.1029/2008EO410004, 2008

Tedesco, M., Fettweis, X., van den Broeke, M. R., van de Wal, R. S. W., Smeets, C. J. P. P., van de Berg, W. J., Serreze, M. C., and Box, J. E.: The role of albedo and accumulation in the 2010 melting record in Greenland, Environ. Res. Lett., 6, 014005, doi:10.1088/1748-9326/6/1/014005, 2011.

Van Angelen, J., van den Broeke, M. R., and van de Berg, W. J.: Momentum budget of the atmospheric boundary layer over the Greenland ice sheet and its surrounding seas, J. Geophys. Res., in press, 2011.

Van de Wal, R. S. W. and Russell, A.: A comparison of energy balance calculations, measured ablation and meltwater runoff near Søndre Strømfjord, West Greenland, Global Planet. Change, 9, 29-38, 1994.

Van de Wal, R. S. W., Greuell, W., van den Broeke, M. R., Boot, W., Snellen, H., Reijmer, C. H., and Oerlemans, J.: Mass balance measurements along a transect in West-Greenland over the period 1990-2003, Ann. Glaciol., 42, 311-316, 2005.

Van de Wal, R. S. W., Boot, W., van den Broeke, M. R., Smeets, C. J. P. P., Reijmer, C. H., Donker, J. J. A., and Oerlemans, J.: Large and Rapid Melt-Induced Velocity Changes in the Ablation Zone of the Greenland Ice Sheet, Science, 321, 111-113, doi:10.1126/science.1158540, 2008. 
Van den Broeke, M. R. and Gallée, H.: Observation and simulation of barrier winds at the western margin of the Greenland ice sheet, Q. J. Roy. Meteor. Soc., 122, 1365-1383, 1996.

Van den Broeke, M. R., Duynkerke, P. G., and Oerlemans, J.: The observed katabatic flow at the edge of the Greenland ice sheet during GIMEX-91, Global Planet. Change, 9, 3-15, 1994.

Van den Broeke, M. R., van As, D., Reijmer, C. H., and van de Wal, R. S. W.: Assessing and improving the quality of unattended radiation observations in Antarctica, J. Atmos. Ocean. Tech., 21(9), 1417-1431, 2004.

Van den Broeke, M. R., Smeets, C. J. P. P., Ettema, J., and KuipersMunneke, P.: Surface radiation balance in the ablation zone of the west Greenland ice sheet, J. Geophys. Res., 113, D13105, doi:10.1029/2007JD009283, 2008a.

Van den Broeke, M., Smeets, P., Ettema, J., van der Veen, C., van de Wal, R., and Oerlemans, J.: Partitioning of melt energy and meltwater fluxes in the ablation zone of the west Greenland ice sheet, The Cryosphere, 2, 179-189, doi:10.5194/tc-2-179-2008, 2008b.
Van den Broeke, M. R., Bamber, J., Ettema, J., Rignot, E., Schrama, E., van de Berg, W. J., van Meijgaard, E., Velicogna, I., and Wouters, B.: Partitioning recent Greenland mass loss, Science, 326, 984-986, 2009a.

Van den Broeke, M. R., Smeets, C. J. P. P., and Ettema, J.: Surface layer climate and turbulent exchange in the ablation zone of the west Greenland ice sheet, Int. J. Climatol., 29, 2309-2323, doi:10.1002/joc.1815, 2009b.

Wientjes, I. G. M. and Oerlemans, J.: An explanation for the dark region in the western melt zone of the Greenland ice sheet, The Cryosphere, 4, 261-268, doi:10.5194/tc-4-261-2010, 2010.

Zwally, H. J., Giovinetto, M. B., Li, J., Cornejo, H. G., Beckley, M. A., Brenner, A. C., Saba, J. L., and Yi, D.: Mass changes of the Greenland and Antarctic ice sheets and shelves and contributions to sea-level rise. 1992-2002, J. Glaciol., 51, 509-527, 2005. 